\title{
Use of effective microorganisms with phytoprotective ceramics in the initial growth of Theobroma cacao L.
}

\section{Uso de microorganismos efectivos con cerámicas fitoprotectoras en el crecimiento inicial de Theobroma cacao L.}

\author{
Nereyda Patty Pérez Palermo ${ }^{l}$, Ena Vilma Velazco Castro ${ }^{l}$ and Cindy Paola Castro Muñoz ${ }^{l}$ \\ ${ }^{1}$ Universidad Nacional Intercultural de la Amazonia, Perú.
}

\begin{abstract}
The research was conducted in the nursery of the National Intercultural University of Amazonia, whose objective was to use effective microorganisms with plant protection ceramics in the initial growth of Theobroma cacao, "common cocoa". The experiment was conducted through a completely randomized design (DCA), with 5 treatments, 10 repetitions and 50 experimental units. The treatments were: T1 (Control); T2 (100 ml of efficient microorganisms (EM) $+20 \mathrm{~g}$ of phytoprotective ceramic (CF)); T3 (200 ml of MS $+20 \mathrm{~g}$ of CF); T4 (300 ml of EM $+20 \mathrm{~g}$ of CF) and T5 (400 ml of EM $+20 \mathrm{~g}$ of CF). As a result, the T3 treatment obtained better growth value in height, diameter and specific leaf area with: $25.56 \mathrm{~cm}, 6.86 \mathrm{~mm}$ and $90.77 \mathrm{~cm} 2$ / g respectively, compared to the control that reached $19.98 \mathrm{~cm} .5 .49 \mathrm{~mm} .49 .32$. Regarding the quality indexes, the ratio of aerial dry biomass / dry root biomass (R BSA / RBSR), lignification index (IL), robustness index (IR) and Dickson quality index (DQI), did not show significant differences between the treatments, but the T3 had higher value over the IR with 3.76, the R BSA / RBSR with 2.45 and DQI with 0.85 , and the T4 had greater value in the IL with 33.68 .
\end{abstract}

Keywords: efficient microorganisms, crop protection ceramics, quality indexes, production of quality seedling.

\section{RESUMEN}

La investigación se realizó en el vivero de la Universidad Nacional Intercultural de la Amazonía, cuyo objetivo fue utilizar microorganismos efectivos con cerámica fitosanitaria en el crecimiento inicial de Theobroma cacao, "cacao común". El experimento se realizó a través de un diseño completamente aleatorizado (DCA), con 5 tratamientos, 10 repeticiones y 50 unidades experimentales. Los tratamientos fueron: T1 (Control); T2 (100 ml de microorganismos eficientes (EM) $+20 \mathrm{~g}$ de cerámica fitoprotectora (CF)); T3 (200 ml de EM + 20 g de FQ); T4 (300 ml de EM + 20 g de CF) y T5 (400 ml de EM + 20 $\mathrm{g}$ de $\mathrm{CF}$ ). Como resultado, el tratamiento $\mathrm{T} 3$ obtuvo un mejor valor de crecimiento en altura, diámetro y área foliar específica con: $25,56 \mathrm{~cm}, 6,86 \mathrm{~mm}$ y $90,77 \mathrm{~cm} 2$ / g respectivamente, en comparación con el control que alcanzó los 19,98 cm. 5,49 mm.

Nereyda Patty Pérez Palermo. ORCID: https://orcid.org/0000-0002-0122-3340 email: palermo0219@gmail.com Ena Vilma Velazco Castro. ORCID: https://orcid.org/0000-0003-2951-6257 email: evelazcoc@unia.edu.pe Cindy Paola Castro Muñoz. ORCID: https://orcid.org/0000-0002-3898-5939 email: cpcastrom36@gmail.com 
49,32. En cuanto a los índices de calidad, la relación de biomasa seca aérea / biomasa de raíz seca (R BSA / RBSR), índice de lignificación (IL), índice de robustez (IR) e índice de calidad de Dickson (DQI), no mostró diferencias significativas entre los tratamientos, pero el T3 tuvo mayor valor sobre el IR con 3.76, el R BSA / RBSR con 2.45 y DQI con 0.85, y la T4 tuvo mayor valor en la IL con 33,68.

Palabras clave: microorganismos eficientes, cerámica de protección de cultivos, índices de calidad, producción de plántulas de calidad.

\section{INTRODUCTION}

$\mathrm{I}^{\mathrm{n}}$ the Ucayali region, around 20,000 hectares of cocoa in various varieties have already been planted, of which 11,484 hectares have been planted in the province of Padre Abad, 6,523 hectares in Coronel Portillo, 2,981 hectares in Atalaya and the others in Purús. (Álvarez, 2016). However, the success of the plantations depends mainly on the use of quality seedlings, which is produced in the nurseries, which can ensure a greater probability of surviving and developing from their establishment in the definitive field, ensuring the greatest survival (Ruano, 2003 as cited in Sáenz, et ál., 2014). Faced with this identified problem, a new alternative to produce quality seedlings is through the application of "Efficient Microorganisms" (mixed culture of three groups of beneficial microorganisms: lactic acid bacteria, phototrophic bacteria and yeasts) and phytoprotective ceramics (diatom rocks formed by seaweed) in the form of irrigation, which will allow to accelerate the growth and development of seedlings and activate the natural defences of the plant, besides, when it comes into contact with the substrate, it generates a protective barrier with beneficial microorganisms around the material, reducing the incidence of diseases housed in the environment (EMPROC, 2017). However, there are no quantitative data related to its effect on the growth and development of cocoa seedlings; Under this premise, the objective of the research was to use effective microorganisms with plant protection ceramics in the initial growth of Theobroma cacao, "common cocoa".

\section{METHODOLOGY}

\section{Location and description of the study area}

The research was carried out in the nursery of the National Intercultural University of the Amazon, located on the Highway to San José km 0.5; geographically located at UTM coordinates: 18L 544858, 9077199 and at 146 meters above sea level, the research was carried out from September to November, the average temperature was $27.1^{\circ} \mathrm{C}$; relative humidity of $85 \%$, and an average annual rainfall of $1,116.5$ $\mathrm{mm}$ (Main Agricultural Meteorological Station of the National University of Ucayali, 2017).

\section{Identification and description of the experimental material}

The experimental material was the "Common" variety cocoa seedlings and for the production of these seedlings the cocoa seeds were extracted from the six-year-old cocoa plot of Mr. Luis Alberto Murrieta Isuiza, identified with DNI No. 21147452, for this the fruit of the plants with the highest Attribution-NonCommercial 4.0 International (CC BY-NC 4.0) production and those that were free of diseases was selected. The plot is located in the Caserío Mojaral, Campo Verde district.

\section{Selection of the mother plant and selection of the fruit}

The plants with the highest production and those that were disease-free were selected within the plantation. Then the large, healthy and well-matured ears were extracted from the trunk or primary branches since they give uniform and more vigorous seeds.

\section{Seed selection and demucilaginate}

The cocoa pod was opened avoiding damaging the seed; then it was divided into three parts; The most vigorous kernels found in the middle third of the ear were selected and the seeds from the extreme thirds were discarded Subsequently, the mucilage was eliminated through rubbing with sawdust. Finally, they were aired under shade for 8 hours.

\section{Substrate preparation}

In preparing the substrate, the following components and proportions were used: 3 of agricultural soil +2 of organic matter (chicken manure) +1 of sand, each of the components was sifted, in a sieve with a $0.5 \mathrm{~cm} \times 0.5 \mathrm{~cm}$ metal mesh. Then the quantities were measured according to the proportions, for which 12 wheelbarrows of black earth, 8 of sand and 4 of organic matter were used, later with the help of a straight shovel the components of the substrate were mixed, until obtaining a mixture homogeneous.

\section{Filling and accommodating bags}

The bags were filled halfway by releasing it from the hands gently against the ground repeatedly at a height of approximately $10 \mathrm{~cm}$ until the filling was completed, this work was carried out in order to make a uniform settlement of the content so that it was not excessively loose. The bags used were made of polyethylene, black, $24 \mathrm{~cm}$ high, $14 \mathrm{~cm}$ wide and $0.1 \mathrm{~mm}$ thick (kilo and a half), with holes distributed at the base of the bag for drainage. A total of 1000 bags were filled and arranged in fifty blocks, with 20 bags for each repetition of the five treatments. The distance between each block was $40 \mathrm{~cm}$, with an area of approximately four meters front $\mathrm{x}$ eight meters deep.

\section{Activation of Effective Microorganisms (AMF)}

For the activation of efficient microorganisms, a 20-litre $(100 \%)$ plastic bucket was used, in which 18 litres of chlorine-free water $(90 \%)$, one litre of molasses ( 5 per cent) and one litre of EM were added. $\cdot 1 \circledR(5$ per cent $)$, then it was mixed until homogenized, later the mixture was placed in a 
ISSNe: 2617-9156

gallon (20L) of clean plastic, hermetically sealed (without air) and left to rest for two weeks in a shaded environment. After two weeks, the gallon where the efficient microorganisms were found was checked and it had a light brown colour, a bittersweet smell (of cane juice) and an acid taste, from that moment the EM was already activated and ready to use.

\section{Pre-germinated seeds}

The pre-germination of Theobroma cacao seeds was carried out in a $1 \mathrm{~m} 2$ bed of wet sawdust, where a certain number of seed was placed and two $\mathrm{cm}$ thick of wet sawdust was placed on them, the same procedure was repeated, forming several layers until covering all the seeds, then the whole bed was covered with banana leaf. A total of 1055 seeds were pre-germinated, equivalent to three $\mathrm{kg}$ of seeds because one $\mathrm{kg}$ contains approximately 350 seeds, this will depend on the size and weight. It was checked daily in the morning to extract the germinated seeds and immediately carry out the manual sowing, making a hole the size of the seed (approximately 2.5 to 3 centimetres) in the centre of the bag and the seed was placed with the radicle (medium approximately 2 to 5 millimetres) downwards, very carefully so that it is not damaged; It was then covered with a light layer of the substrate.

\section{Determination of concentrations of Effective Microorganisms (EM) for each treatment}

It was determined to work with 2, 4, 6 and 8 per cent of efficient microorganisms because Merino (2013) mentions in his research that doses greater than $10 \%$ cause a certain degree of toxicity in plants, which is reflected with a decrease in their growth. For this, the percentages based on five litres, equivalent to $100 \%$, were calculated with the rule of three simple. Obtaining the following amounts to use for each treatment: (a) Treatment two: $100 \mathrm{ml}$ (at 2 percent), (b) treatment three: $200 \mathrm{ml}$ (at 4 percent), (c) treatment four: 300 $\mathrm{ml}$ (at 6 percent) and (d) Treatment Five: $400 \mathrm{ml}$ (at 8 percent).

\section{Determination of concentration of Phytoprotectant Ceramic (EM • CERAMICA ${ }^{\circledR}$ Phytoprotectant) for each treatment}

It was determined to work with 2 per cent of a kilo, according to the indications of the technical sheet of the product, it is advisable to work with 1 or 2 per cent of the total product. Therefore, $20 \mathrm{~g}$ was used for treatment two, three, four and five, except for treatment one, which did not apply anything because it was the control.

\section{Application of Effective Microorganisms (EM) with Phytoprotectant Ceramic (EM - CERAMICA ${ }^{\circledR}$ Phytoprotectant) for each treatment}

The application began with treatment two, for which 200 $\mathrm{ml}$ of activated efficient microorganisms were quantified in a $500 \mathrm{ml}$ graduated jar, once quantified it was added to a fumigation backpack (10 litres), then the $20 \mathrm{~g}$ of phytoprotectant Ceramic and finally the water was added to complete the 5 litres, then it was stirred until homogenized, the mixture was applied as irrigation to the seedlings, wetting the leaves and the substrate well. This same procedure was repeated three times until the application of all the treatments was completed, each with its respective concentrations previously determined. The applications began at 7:00 a.m. and ended at approximately 9:00 a.m. they were made three times a week (Monday, Wednesday and Friday) throughout the evaluation process.

\section{Irrigation}

The irrigation was carried out with a hose ( 5 meters) in the form of rain, for $10 \mathrm{~min}$, once a day, watering approximately 60 litres of water, but on extremely sunny days it was also watered in the afternoon.

\section{Weed control}

The weeds that developed in the bags and also in the streets were removed manually.

\section{Pest control}

The incidence of attack by grasshoppers (Caeliferous) that cut the apex of some seedlings was controlled with a single application of an organic repellent prepared from $500 \mathrm{ml}$ of ground chili, $200 \mathrm{ml}$ of ground garlic and one litre of activated effective microorganisms. All this was added in a fumigation backpack and water was added to make up 5 litres, and it was applied by spraying with a backpack on all the seedlings.

\section{Evaluation of variables in the nursery}

The first measurement of the variables was carried out 24 days after sowing, then weekly until 80 days after sowing, for each repetition, five seedlings were randomly selected (from the centre to avoid the effect of the edges) and evaluated the following variables:

\section{- Diameter}

Before carrying out the diameter measurement, with an indelible marker, a mark was made in the area where a clear colour difference was observed between the stem and the root of each of the seedlings to be evaluated, to always measure the same place and thus avoid bias. Then with a vernier approximating to tenths of a millimetre, the diameter measurement was made at the indicated mark.

\section{- Height}

The height measurement was performed with a metal ruler graduated in centimetres, from the mark indicated in the previous procedure to the apex of the terminal bud.

\section{Evaluation of variables in the laboratory}

At the end of the nursery evaluations, 10 plants were extracted at random, for each treatment (1 plant for each repetition), the following variables were evaluated:

\section{- Leaf area}

To determine the leaf area of the plants, five seedlings were selected at random, for each treatment (one for each repetition), the following Richard's method was used (1969) as cited in Sáenz et ál. (2015) where, first the foliage of each plant was weighed and then the silhouettes of all the leaves of the plant were drawn on graph paper, then carefully cut with a scalpel, then all of them were weighed together on a gramera scale. After a square 
ISSNe: 2617-9156

decimetre of the same paper $(1 \mathrm{~cm} 2)$ was cut and weighed, then the leaf area was calculated by a simple rule of three, with the weight of the paper of $1 \mathrm{~cm} 2$ and the weight that represents the total of the leaves drawn of the plant. Finally, the specific leaf area was estimated with the formula:

$$
A F E=\frac{\text { leaf area }}{\text { foliage weight }}
$$

\section{Fresh weight of the aerial part and the root}

To calculate the fresh weight of the aerial part and the root, with a pruning shear the aerial part was separated from the root part, then both parts (aerial biomass and root biomass) were weighed one by one on a digital scale at the precision of one-hundredth of a gram.

\section{Dry weight of the aerial part and the root}

The dry weight of the aerial part and the root was calculated, placing the samples inside kraft paper bags, and drying was carried out in the oven, for 72 hours at a temperature of $70^{\circ} \mathrm{C}$. Finally, the dry weight of both parts of the plant was calculated on a digital scale to a precision of one-hundredth of a gram.

\section{Determination of quality indices}

It was evaluated 80 days after sowing and the results were recorded in the respective format. Finally, with the data of the previously mentioned variables, the following quality indices of the seedlings were determined:

Robustness or Slenderness Index

$$
R I=\frac{\text { height }}{\text { root neck diametre }}
$$

Lignification Index

$$
L I=\frac{\text { total dry weight }}{\text { total wet weight }}
$$

Aerial dry biomass / root dry biomass ratio (ADB / RDB)

Dickson's Quality Index (DQI)

$$
A D B / R D B=\frac{\text { aerial dry biomass }}{\text { root dry biomass }}
$$

$$
D Q I=\frac{\text { total dry weight }}{\frac{\text { height }}{\text { diametre }}+\frac{\text { aerial dry biomass }}{\text { root dry biomass }}}
$$

\section{Data processing}

The experiment was conducted using a completely randomized design (DCA), with 5 treatments, 10 repetitions, and 50 experimental units. The treatments were: T1 (Control); T2 $(100 \mathrm{ml}$ of efficient microorganisms $(\mathrm{EM})+20 \mathrm{~g}$ of phytoprotectant ceramic (CF)); T3 (200 ml of MS + $20 \mathrm{~g}$ of FT); T4 (300 ml of MS $+20 \mathrm{~g}$ of CF) and T5 (400 $\mathrm{ml}$ of MS $+20 \mathrm{~g}$ of CF). At the end of the execution of the investigation, the data were subjected to the analysis of variance and, as the significant effect of the treatments was observed, the analysis of means was carried out with the Tukey's multiple range test $(\mathrm{p} \leq 0.05)$, with the aid of the SSPS computer program, version 21.

\section{RESULTADOS Y DISCUCIONES}

\section{Seedling height}

Before the evaluation of the height of the cocoa seedlings, the germination process was recorded. Likewise, for the germination, the cocoa seeds were conditioned in a pregerminating bed. A $99.05 \%$ germination of seeds was obtained, of which the highest germination percentage was reached on the third day after placing them in the pregermination bed with $45.59 \%$ germination. The emergence of the cotyledons (phosphorite stage) occurred from eight days after planting in the bags, becoming uniform up to 15 days in all treatments. On the other hand, Adriazola (2003) as cited in Merino (2013) mentions that germination is irregular and the highest percentage of germination takes place 8 to 12 days after sowing. Besides, about the Czabator index, $80.3 \%$ is an indicator of good germination vigour and studies affirm that high vigour is synonymous with a high growth rate, reflected in the production of normal seedlings (Adu et ál., 2017 as cited in López and Gil, 2017). Therefore, the results found with the present study are superior, obtaining $99.05 \%$ germination.

Analysis of variance (ANOVA) was applied to the averages of the height of plants evaluated from 24 days to 80 days after sowing, the results of which showed that the treatments did not present significance until 45 days, but from the 52 days if there is a significant difference between the treatments, according to the $\mathrm{F}$ test at $5 \%$ probability.

Once the significant differences $(\mathrm{p} \leq 0.05)$ were verified for the variable growth in height of Theobroma cacao seedlings, the Tukey test was applied to find differences between the treatments, in table 1 it can be observed that at 52 days the T2 treatments, T3, T4 and T5 are different from T1, this same behaviour can be observed up to 80 days after sowing. In this regard, Martínez (2004) as cited in Merino (2013), states that the beneficial effect of fertilizers on plants is manifested after 30 days of its application. In this sense, it can be stated that the effect of Microorganisms is clearly evident from 28 days after the first application, this is corroborated with IDIAF (2009) as cited in Toloambo (2012) which indicates that the antioxidant effects of these microorganisms they pass directly to the soil and indirectly to the plants.

\section{Table 1.}

Tukey's multiple range test $(\mathrm{p} \leq 0.05)$, for the variable height (cm) of Theobroma cacao for the days evaluated. 
Seeding height (cm)

\begin{tabular}{rrrrrrrrrrr}
\hline & \multicolumn{8}{c}{ Days of evaluation } \\
Treatments & $\mathbf{2 4}$ & $\mathbf{3 1}$ & $\mathbf{3 8}$ & $\mathbf{4 5}$ & $\mathbf{5 2}$ & $\mathbf{5 9}$ & $\mathbf{6 6}$ & $\mathbf{7 3}$ & $\mathbf{8 0}$ \\
\hline T1 & $17.87 \mathbf{a}$ & $18.06 \mathbf{a}$ & $18.29 \mathbf{a}$ & $18.58 \mathbf{a}$ & $18.83 \mathbf{a}$ & $19.06 \mathbf{a}$ & $19.35 \mathbf{a}$ & $19.58 \mathbf{a}$ & $19.98 \mathbf{a}$ \\
T2 & $18.25 \mathbf{a}$ & $18.47 \mathbf{a}$ & $18.93 \mathbf{a}$ & $19.51 \mathbf{a}$ & $20.05 \mathbf{b}$ & $20.82 \mathbf{b}$ & $22.22 \mathbf{b}$ & $23.42 \mathbf{b}$ & $24.48 \mathbf{b}$ \\
T3 & $18.17 \mathbf{a}$ & $18.51 \mathbf{a}$ & $19.07 \mathbf{a}$ & $19.9 \mathbf{a}$ & $20.39 \mathbf{b}$ & $21.04 \mathbf{b}$ & $22.56 \mathbf{b}$ & $24.1 \mathbf{b}$ & $25.56 \mathbf{b}$ \\
T4 & $18.06 \mathbf{a}$ & $18.38 \mathbf{a}$ & $18.83 \mathbf{a}$ & $19.54 \mathbf{a}$ & $20.17 \mathbf{b}$ & $20.71 \mathbf{b}$ & $22.38 \mathbf{b}$ & $23.39 \mathbf{b}$ & $24.4 \mathbf{b}$ \\
T5 & $18.05 \mathbf{a}$ & $18.42 \mathbf{a}$ & $18.99 \mathbf{a}$ & $19.65 \mathbf{a}$ & $20.17 \mathbf{b}$ & $20.82 \mathbf{b}$ & $22.39 \mathbf{b}$ & $23.46 \mathbf{b}$ & $24.22 \mathbf{b}$ \\
\hline
\end{tabular}

Equal letters in the same column are not significant according to Tukey's test at $5 \%$ probability

In figure 1, the average results of the growth in height of the Theobroma cacao seedlings are presented, which were evaluated from 24 to 80 days after sowing seeds in the nursery, where all the seedlings at 24 days later from sowing they had an average height of $18.08 \mathrm{~cm}$; However, after 52 days, it is observed that treatments T2, T3, T4 and T5 exceed treatment $\mathrm{T} 1$ in growth, with treatment $\mathrm{T} 3$ being slightly higher with $25.56 \mathrm{~cm}$ in height at 80 days, said treatment (200 $\mathrm{ml}$ of activated efficient microorganisms $+20 \mathrm{gr}$ of phytoprotective ceramic). A similar study was carried out by Merino (2013) who showed that the treatments bocashi +
MEC $®$ (Efficient Microorganisms), Gaicashi + MEC $®$ and Compost + MEC $\AA$, register the highest averages for height at 112 days after sowing of Theobroma cacao seeds, for which it shows an average of $29.01,27,28 \mathrm{~cm}$ respectively, with respect to the control that obtained an average of $20.03 \mathrm{~cm}$. Rodríguez (2013) for his part, conducted a study on the phenotypic characteristics of cocoa (Theobroma cacao) in a nursery with covers of $15 \times 20 \mathrm{~cm}(6 \times 8$ inches $)$ similar to the size used, obtaining an average height of $23 \mathrm{~cm}$ at the 75 days. The results obtained were acceptable according to the average height obtained by the aforementioned authors.

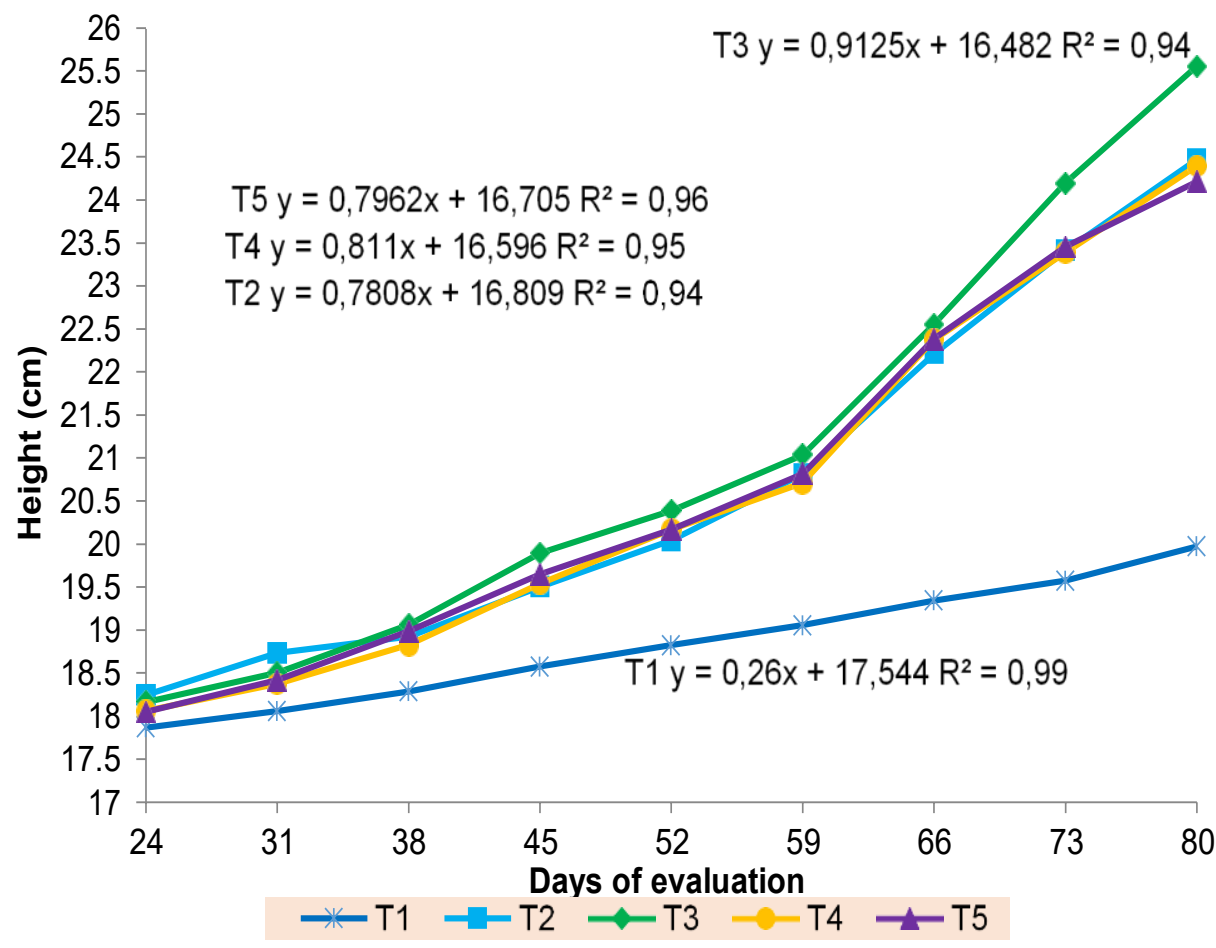

Figure 1. Height growth of Theobroma cacao seedlings during the days evaluated.

For all the above, it should be noted that the result of the physicochemical analysis of the substrate used for the treatments shows that it has a frank texture, with a slightly alkaline $\mathrm{pH}$, with a low level of organic matter, nitrogen and potassium, a high level of, but These physical characteristics are not optimal for cocoa cultivation, therefore this soil does not meet the average values to be used in the production of cocoa seedlings. However, in the study carried out, a good average height was obtained, this can be attributed to the fact that efficient microorganisms are a mixture of three groups of microorganisms: Phototrophic bacteria, Lactic acid bacteria and Yeasts, which increase the availability of nutrients for plants. , and provide beneficial substances such as hormones, amino acids and antioxidant substances produced by the same microorganisms, also improve the structure of the soil and 
ISSNe: 2617-9156

compete with pathogens for space and food, thus reducing the populations of pathogens in the soil (EMPROTEC 2017).

\section{Stem diameter}

The analysis of variance (ANOVA) was applied to the growth in diameter of Theobroma cacao seedlings, from 24 days to 80 days after sowing, the results of which showed that the treatments did not present significance until 45 days, but from of the 52 days if there is a significant difference between the treatments, according to the $\mathrm{F}$ test at $5 \%$ probability.

Once the significant differences $(\mathrm{p} \leq 0.05)$ were verified for the variable growth in diameter of Theobroma cacao seedlings, the Tukey test was applied to find differences

Seeding diametre $(\mathrm{mm})$

\begin{tabular}{|c|c|c|c|c|c|c|c|c|c|}
\hline \multirow[b]{2}{*}{ Treatments } & \multicolumn{9}{|c|}{ Days of evaluation } \\
\hline & 24 & 31 & 38 & 45 & 52 & 59 & 66 & 73 & 80 \\
\hline T1 & $4.01 \mathrm{a}$ & $4.16 \mathrm{a}$ & $4.38 \mathbf{a}$ & $4.56 \mathbf{a}$ & $4.73 \mathrm{a}$ & $4.89 \mathbf{a}$ & $5.08 \mathrm{a}$ & $5.28 \mathrm{a}$ & $5.49 \mathrm{a}$ \\
\hline $\mathbf{T 2}$ & $4.14 \mathbf{a}$ & $4.33 \mathbf{a}$ & $4.72 \mathbf{a}$ & $4.93 \mathbf{a}$ & $5.29 \mathbf{b}$ & $5.63 \mathrm{~b}$ & $5.93 \mathbf{b}$ & $6.18 \mathbf{b}$ & $6.53 \mathbf{b}$ \\
\hline T3 & $4.18 \mathbf{a}$ & $4.46 \mathbf{a}$ & $4.85 \mathbf{a}$ & $5.12 \mathbf{a}$ & $5.43 \mathbf{b}$ & $5.84 \mathbf{b}$ & $6.18 \mathbf{b}$ & $6.5 \mathbf{b}$ & $6.86 \mathrm{c}$ \\
\hline T4 & $4.18 \mathbf{a}$ & $4.41 \mathbf{a}$ & $4.77 \mathbf{a}$ & $5.01 \mathrm{a}$ & $5.25 \mathbf{b}$ & $5.58 \mathbf{b}$ & $5.99 \mathbf{b}$ & $6.24 \mathbf{b}$ & $6.54 \mathbf{b}$ \\
\hline T5 & $4.16 \mathbf{a}$ & $4.47 \mathbf{a}$ & $4.79 \mathbf{a}$ & $4.99 \mathbf{a}$ & $5.31 \mathbf{b}$ & $5.65 \mathrm{~b}$ & $5.99 \mathbf{b}$ & $6.26 \mathbf{b}$ & $6.58 \mathbf{b}$ \\
\hline
\end{tabular}

Equal letters in the same column are not significant according to Tukey's test at 5\% probability

A similar study was carried out by Merino (2013) who

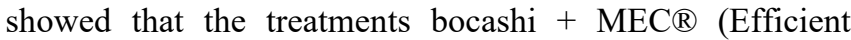
Microorganisms), Gaicashi + MEC $\AA$ and Compost + MEC $\AA$, register the highest averages for the diameter at 112 days after sowing of Theobroma cacao seeds, for which it shows an average of $7.4,7.2$ and 6.8 millimetres respectively, concerning the control that obtained an average of 5.6 between the treatments, in table 2 it can be observed that at 52 days the $\mathrm{T} 2$ treatments, $\mathrm{T} 3, \mathrm{~T} 4$ and $\mathrm{T} 5$ are different from $\mathrm{T} 1$, this same behaviour can be observed up to 73 days, but at 80 days $\mathrm{T} 3$ is significantly different concerning all treatments.

\section{Table 2.}

Tukey's multiple range test $(\mathrm{p} \leq 0.05)$, for the diameter variable $(\mathrm{mm})$ of Theobroma cacao for the days evaluated.

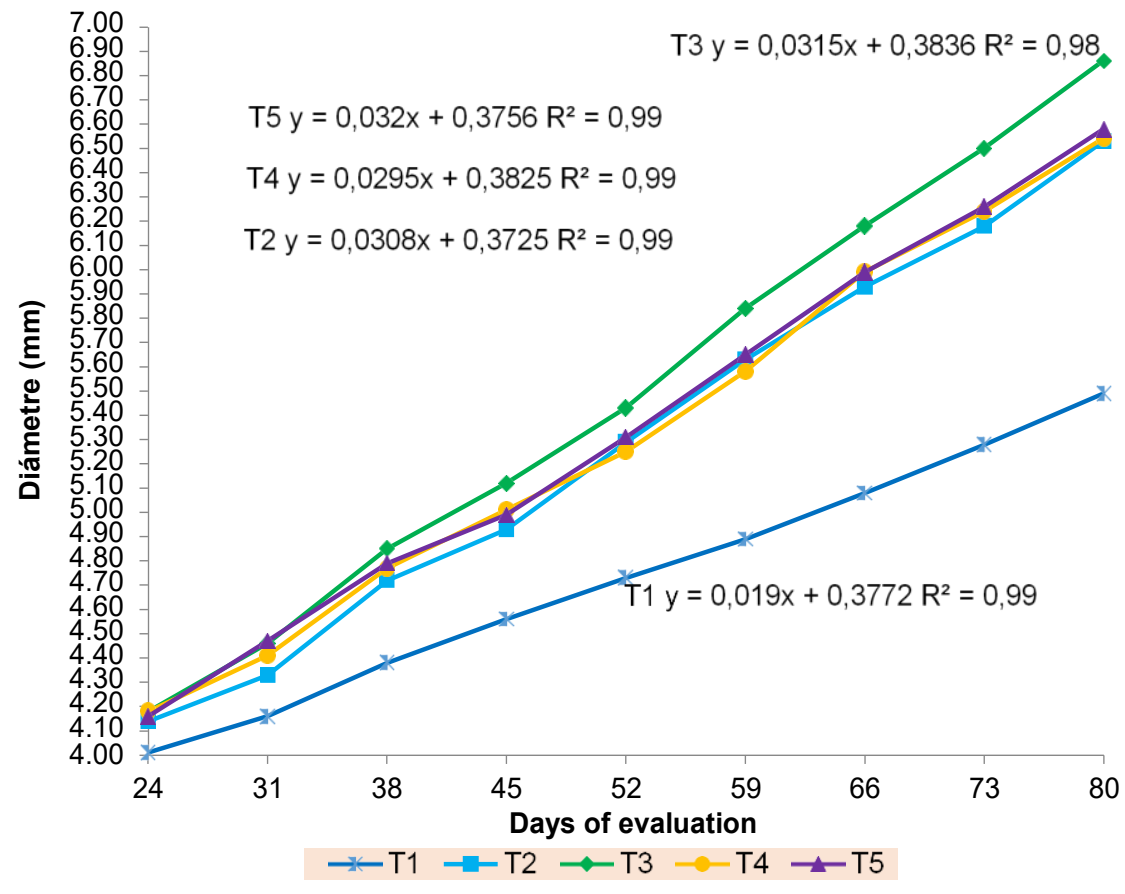

Figure 2. Growth in diameter of Theobroma cacao seedlings during the days evaluated.

Finally, regarding the growth in diameter of the cocoa seedlings at 80 days, the T1 treatment is lower than the other millimetres. However, the results obtained are higher than those obtained with Theobroma cacao seedlings that were propagated for 80 days, this can be attributed to the fact that the seedlings evaluated by the aforementioned author have 22 more days of difference. This is corroborated with the results obtained by Rodríguez (2013) who obtained an average diameter of $3 \mathrm{~mm}$ at 75 days. 
ISSNe: 2617-9156

Landis (1990) as cited in Sáenz et ál. (2010) state that a high survival rate $(>80 \%)$ is achieved when the plants are 5 to 6 $\mathrm{mm}$ in diameter. Besides, plants with a diameter greater than $5 \mathrm{~mm}$ are more resistant to bending and better tolerate damage by pests and harmful fauna, but this varies according to the species). This matches Davide and Faria (2008) as cited in Abanto (2016) which indicate that plants with a basal diameter of less than $3 \mathrm{~mm}$ are easily damaged by ants and torrential rains. In this sense, it can be considered that the cocoa seedlings produced with the incorporation of adequate concentrations of Efficient Microorganisms with
Phytoprotectant Ceramic are within the ranges established and discussed by the aforementioned authors.

\section{Specific leaf area (AFE)}

To the averages of the Specific Leaf Area, the analysis of variance (ANOVA) was applied, the results of which showed that the treatments present a significant difference, according to the $\mathrm{F}$ test at $5 \%$ probability. Having verified the significant differences $(\mathrm{p} \leq 0.05)$ for the specific leaf area growth variable of Theobroma cacao seedlings, the Tukey test was applied to find differences between the treatments.

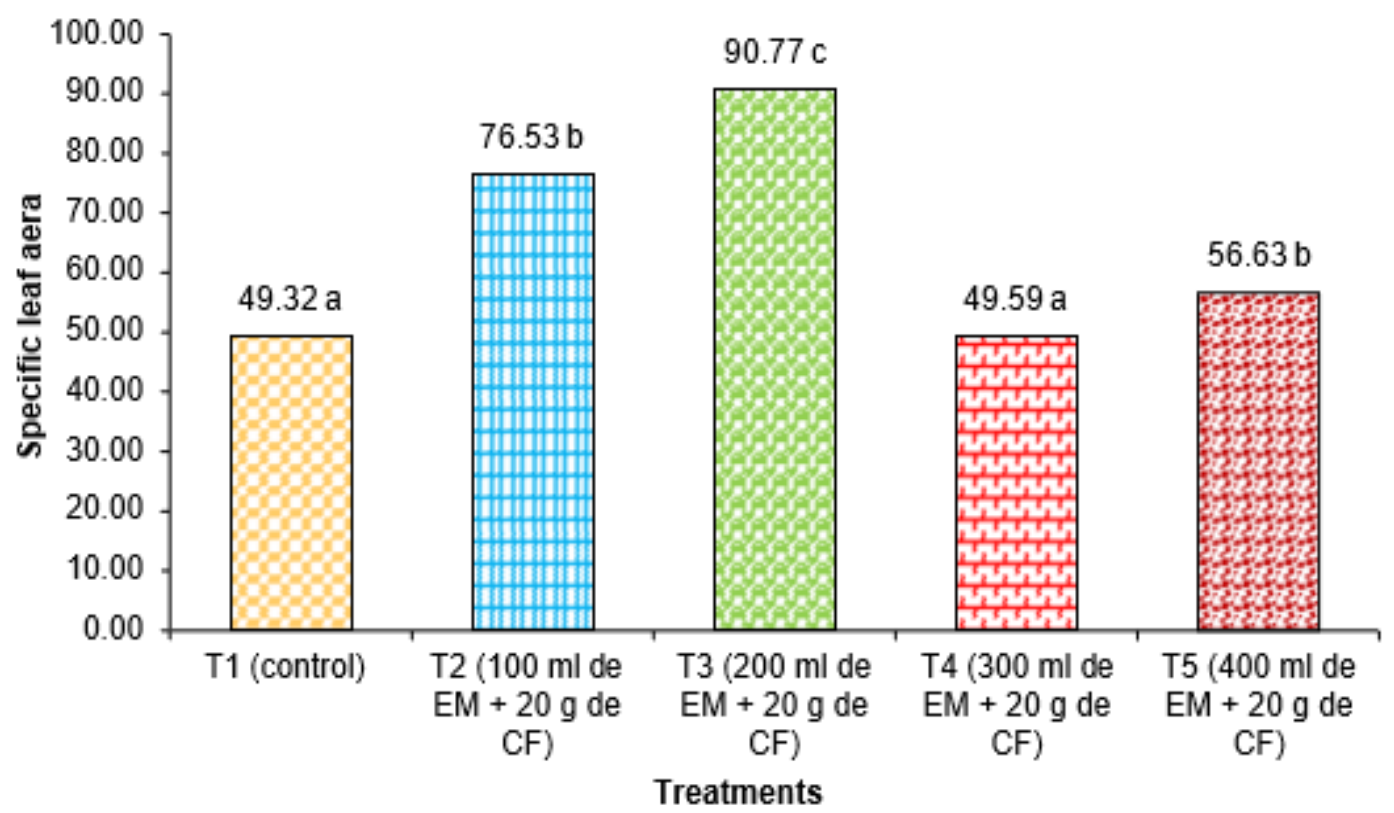

Figure 3. Specific foliar area of Theobroma cacao seedlings by effect of the type of treatment, 80 days after sowing the seeds.

In figure 3. It is observed that $\mathrm{T} 3$ obtained the maximum value with 90.77 , followed by the $\mathrm{T} 2$ treatment with 76.53 . These results are important because an increase in the specific foliar area implies that the leaf invests less biomass per unit area (Mello, 2006 as cited in Sáenz et ál., 2015). In other words, the total leaf area of the plants influences the ability of the leaves to intercept photosynthetically active radiation, which is used as an energy source for the production of food compounds and tissue formation.

Likewise, the $\mathrm{T} 2$ treatment has similar behaviour with a value of 76.53 , therefore it can be said that the amount of concentration of efficient microorganisms used in T3 and T2, cause a significant influence on the specific leaf area of cocoa plants at 80 days after sowing cocoa beans.

Finally, it can be said that the application of microorganisms to the foliage strengthens and stimulates the development of plants, in addition to improving the synthesis of nutrients and in general the photosynthetic activity of plants. This is confirmed by Silva (2009) as cited in Toloambo (2012) who mentions, efficient microorganisms increase photosynthetic capacity through greater foliar development.

\section{Quality indices}

The quality indices evaluated will help to determine the measurement values to identify quality seedlings, since according to More (2003) as cited in Saenz (2015) many times the success of the plantations depends mainly on the quality of the plant that is produced in Nurseries, while Leyva et ál. (2008) as cited in Saenz (2015) affirms that to achieve quality plants, cultural techniques must be developed that start from the nursery, the type of substrate, the type of container and the quality of the seeds Being the substrate an important factor in obtaining quality plants.

\section{Robustness Index (RI)}

Analysis of variance (ANOVA) was applied to the averages of the Robustness Index, the results of which showed that the treatments did not present a significant difference, according to the $\mathrm{F}$ test at $5 \%$ probability.

In figure 4 , it can be seen that all the treatments reached similar values below 6 , with treatments $\mathrm{T} 3, \mathrm{~T} 2$ and $\mathrm{T} 4$ the highest with $3.76,3.75$ and 3.73 , followed by treatments $\mathrm{T} 1$ and T5 with 3.64 and 3.69. 


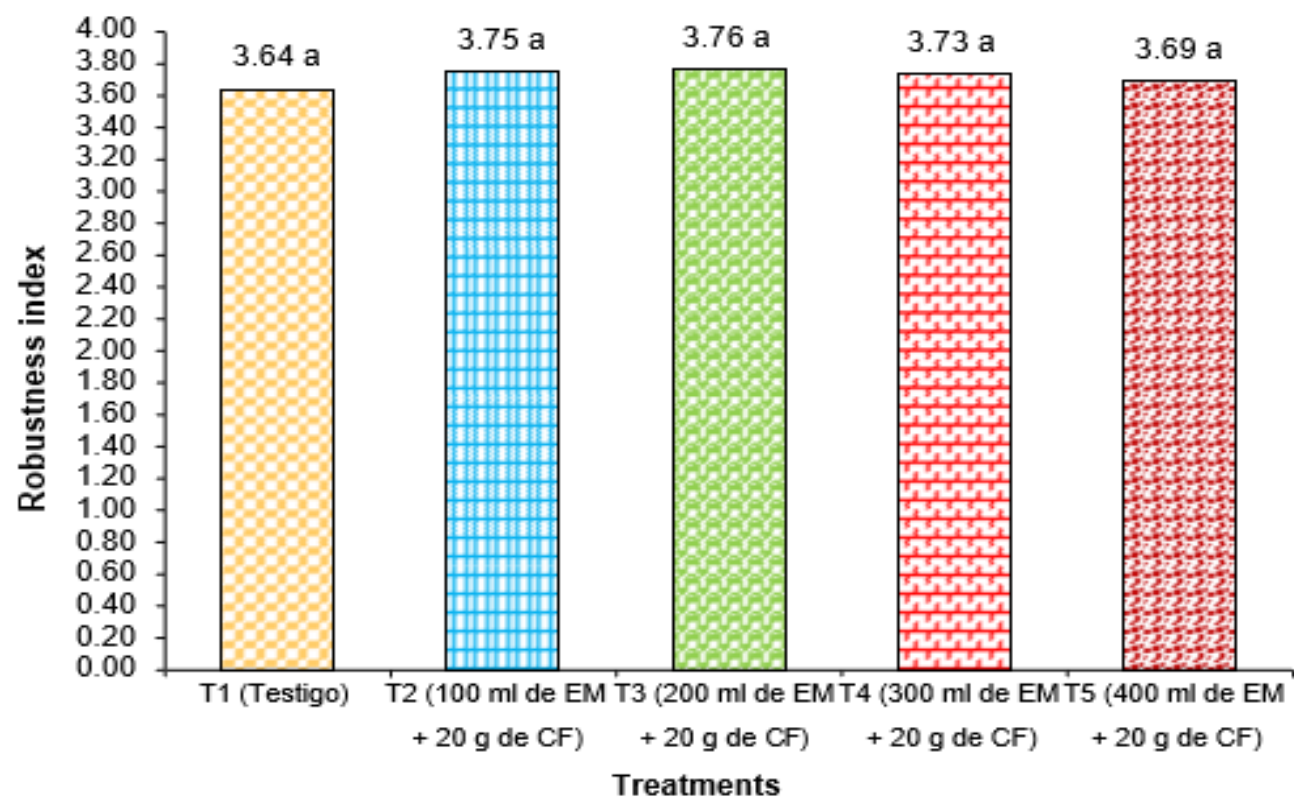

Figure 4. Robustness index of Theobroma cacao seedlings by the effect of the type of treatment, 80 days after sowing the seeds.

In this regard, Rodríguez (2008) as cited in Saenz (2010) mentions that the value of the robustness index must be less than six and indicates that these are small trees that are associated with a better quality of the plant and indicate that it is more robust and with vigorous stem, suitable for sites with limited humidity, on the other hand, values higher than six indicate a disproportion between growth in height and diameter, such as elongated stems with thin diameters, which dispose them to damage by wind and drought. Therefore, the values obtained in this investigation are favourable in all treatments, because it is within the acceptable range. However, for the Theobroma cacao species, there are still no established robustness ranges, so these indices lower than six are a good indicator of the vigour of the plants, where T3 presents a higher robustness index, this is due to the effect of the concentration of efficient microorganisms, which positively favoured the seedlings. Therefore, he recommends that the lower the value obtained in the height/diameter ratio for tropical species, the greater the vigour in the plant.

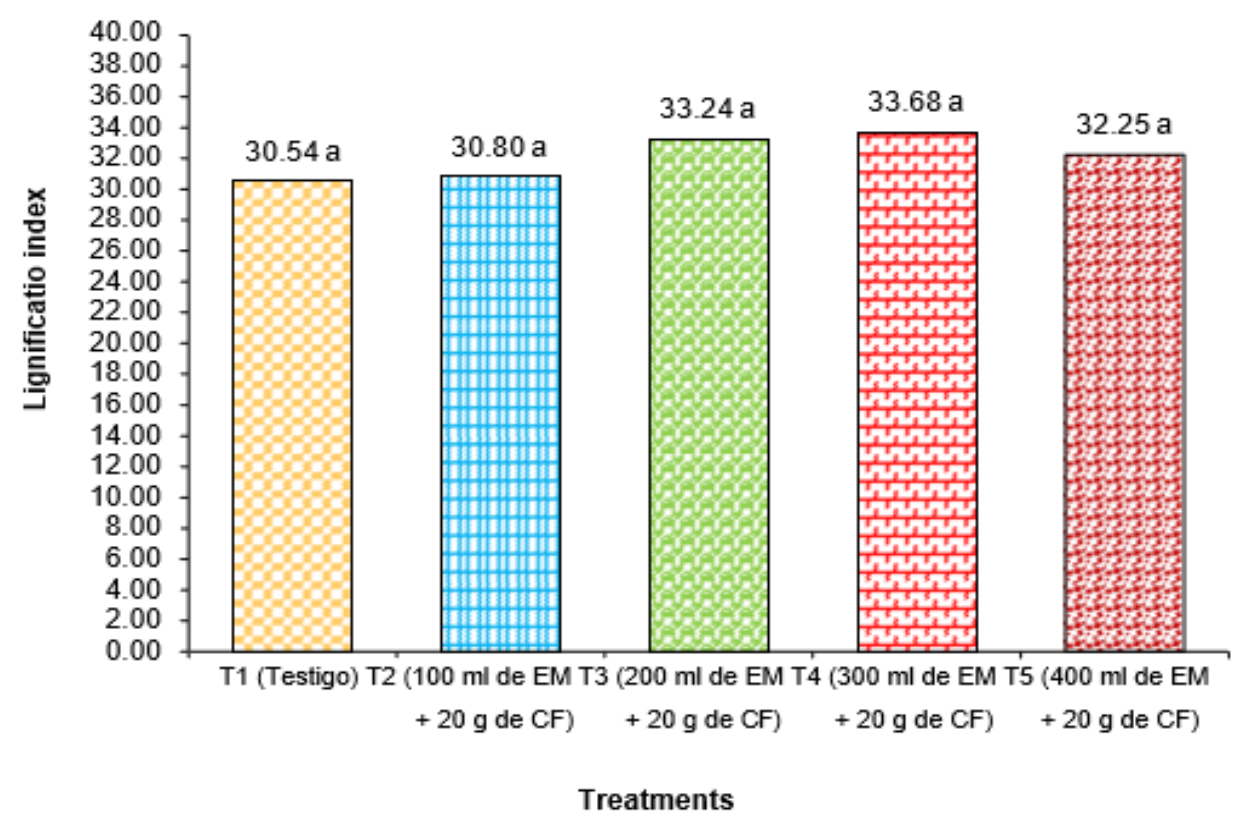

Figure 5. Lignification index of Theobroma cacao seedlings by the effect of the type of treatment, 80 days after sowing the seeds. 
It should be mentioned that the lignification of the plants is closely related to the moisture content of the substrate, in this case, there was no significant difference because a type of substrate was used for all treatments (Mc Tiernan et ál., 2003 as cited in Orozco et ál., 2010).

On the other hand, Orozco et ál. (2010) carried out a study with organic substrates using different sizes of containers and in different nurseries, determining the lignification index for tepemezquite and red guaje species, it was $30.80 \%$ and $24.18 \%$, respectively, which are high, while the species pink purple red cedar the lignification index for both species was acceptable with $20.28 \%$ and $21.77 \%$ respectively, which means that they were subjected to low water stress.

In this sense, it can be affirmed that the Theobroma cacao species reached a high lignification index, probably due to good irrigation management in the nursery stage.

\section{Airborne dry biomass / Root dry biomass ratio (R ADB / RDB)}

Analysis of variance (ANOVA) was applied to the averages of the Airborne Dry Biomass / Root Dry Biomass Ratio, the results of which showed that the treatments did not present a significant difference, according to the 5\% probability $\mathrm{F}$ test. In figure 6 , it is observed that treatment $\mathrm{T} 1$ had the maximum influence on the said index (4.09), followed by T2 (3.69), T4 (2.57) and T5 (2.83). However, Thompson (1985) as cited in Sáenz et ál. (2015), mentions that these values should not be greater than 2.5 , because they would indicate a disproportion between the aerial part and an insufficient root system to provide energy to the aerial part of the plant. Likewise, treatment T3 (2.45), whose result shows that it is within the optimal values according to what was mentioned by Thompson, a good relationship between the aerial part and the root system should fluctuate between 1.5 to 2.5 .

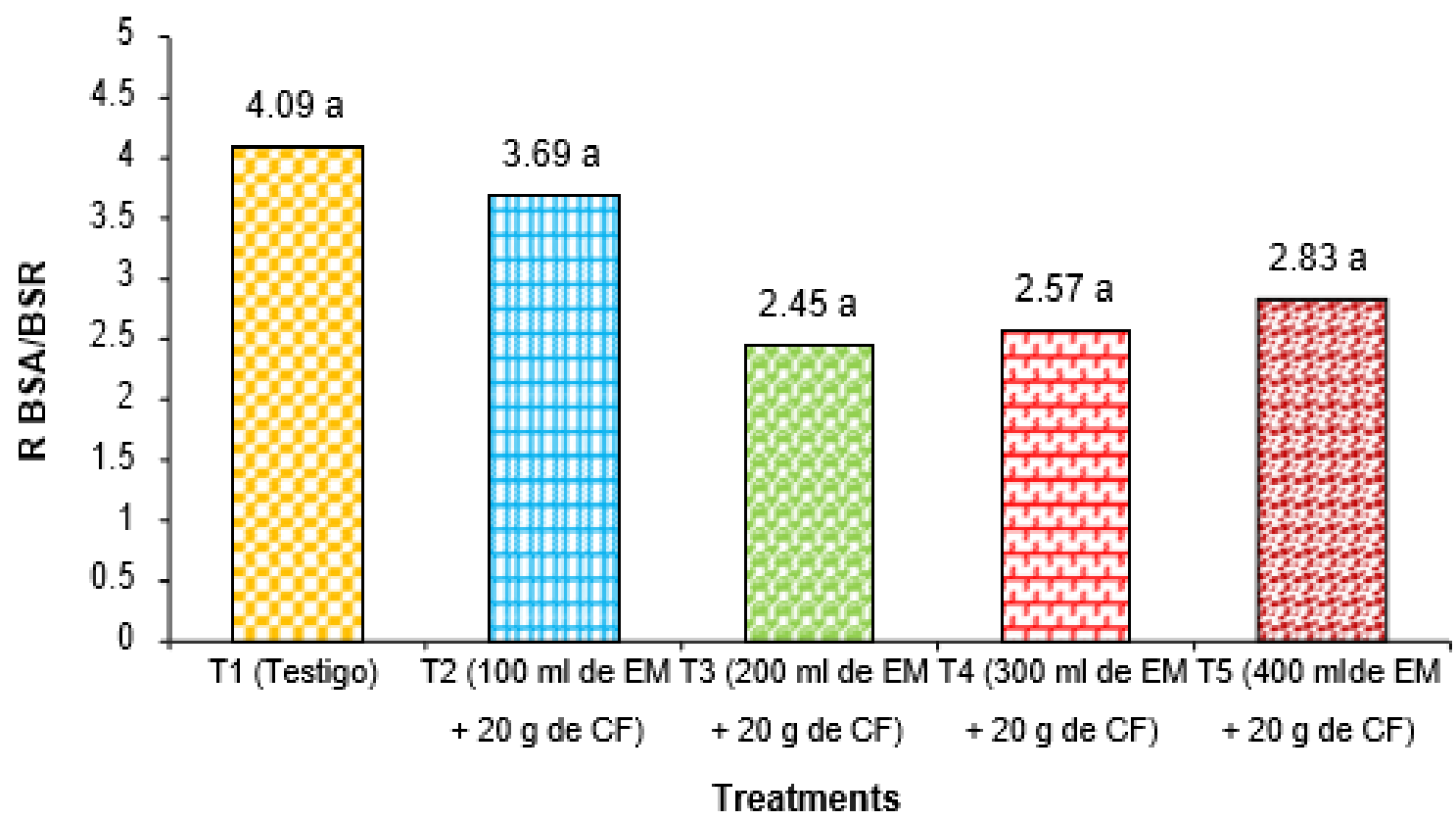

Figure 6. The ratio of aerial dry biomass and root dry biomass of Theobroma cacao seedlings by the effect of the type of treatment, 80 days after sowing the seeds.

On the other hand, Saenz et ál. (2015) obtained results from 1.89 to 2.33 , working with Schizolobium amazonicum plants, using different types of substrates with organic inputs, showing that the use of organic substrates helps to obtain plants with a good relationship between aerial biomass and biomass. root.

In this way, it can be stated that the concentration of efficient microorganisms used in T3 influenced the aerial dry biomass/root dry biomass ratio, because there is a balance between the aerial part and the root system, which is the absorbent part. of humidity.

\section{Dickson's Quality Index (DQI)}

Analysis of variance (ANOVA) was applied to the averages of the Dickson Quality Index, the results of which showed that the treatments did not present a significant difference, according to the $\mathrm{F}$ test at $5 \%$ probability.

In figure 7 , it is observed that treatment $\mathrm{T} 3$ obtained the best DQI with 0.85 , followed by treatments $\mathrm{T} 5$ and $\mathrm{T} 4$ with 0.74 and 0.71 respectively, while treatments $\mathrm{T} 2$ and $\mathrm{T} 1$ obtained 0.57 and 0.43 . However, Tukey's test determined that there is no significant difference between all the treatments. 


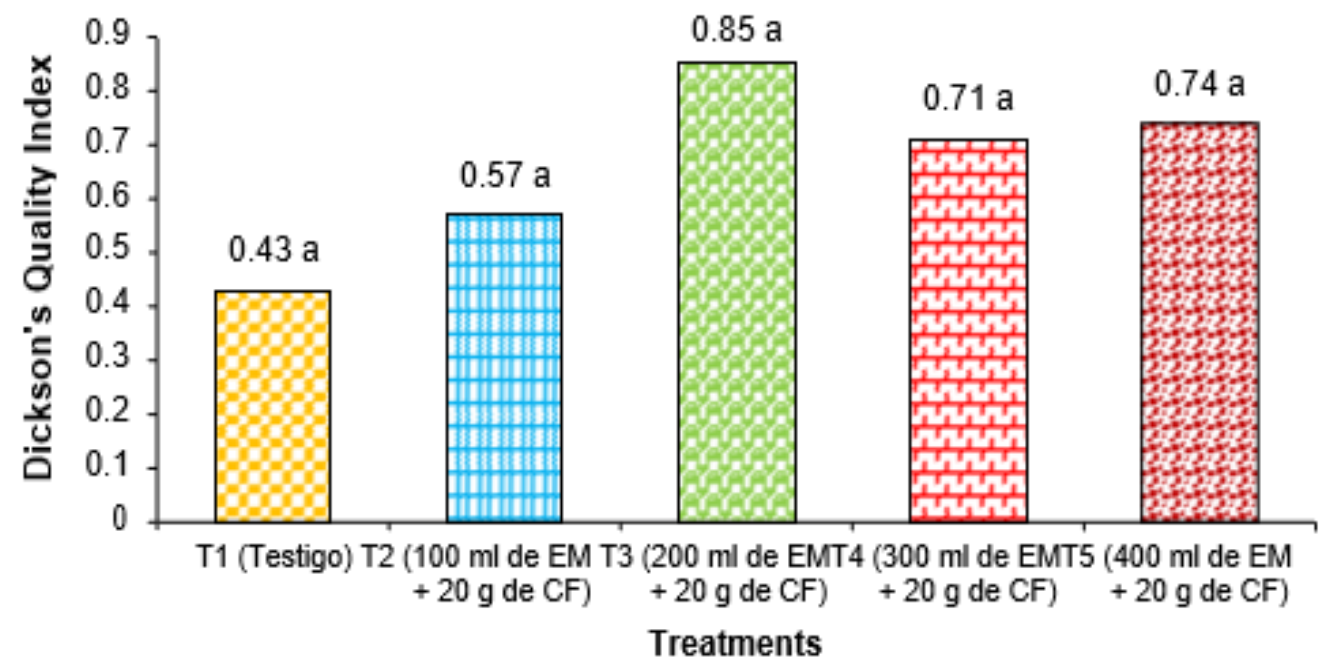

Figure7. Dickson's quality index of Theobroma cacao seedlings by effect of the type of treatment, at 80 days after sowing the seeds.

In this regard, Fonseca (2002) as cited in Abanto et ál. (2016) mention that the DQI is a good indicator, as it weighs important characteristics for the evaluation of the quality of the plants and considers the vigour and balance of the mass distribution throughout the plant. In this sense, Silva et ál. (2013) as cited in Abanto et ál. (2016) indicate that the higher this index, the higher the quality of the plants in the nursery. The same authors indicate that, for a plant to be considered quality, the minimum DQI value must be 0,20 . According to the results, it can be stated that the DQI values verified in this study exceed that mentioned by Silva et ál. (2013) to the indicating that the plants produced with efficient microorganisms are within the quality parameters and suitable for the final field. Likewise, it is necessary to highlight that the DQI of cocoa plants improved with increasing concentrations, with T3 being the best concentration of efficient microorganisms, as it presented the highest value. However, it should be taken into account that these quality indices are used for the first time in the production of Theobroma cacao seedlings, so more studies should be carried out on this species.

\section{Conclusions}

Under the conditions of the experiment, it is possible to conclude:

- For the variable growth in height at 80 days after sowing seeds, treatment $\mathrm{T} 3$ the one that obtained the best numerical value with $25.56 \mathrm{~cm}$, compared to the control that reached $19.98 \mathrm{~cm}$.

- For the growth variable in diameter, 80 days after sowing the seeds, the $\mathrm{T} 3$ treatment obtained a better value with $6.86 \mathrm{~mm}$, compared to the control that reached $5.49 \mathrm{~mm}$.

- For the variable Specific Foliar Area (AFS) at 80 days after sowing the seeds, the $\mathrm{T} 3$ treatment obtained a better value with 90.77 , compared to the control that reached a value of 49.32 .
- For the variable Quality Indices at 80 days after sowing the seeds, T3 obtained a higher value on the robustness index (IR) with 3.76, the ratio of aerial dry biomass/root dry biomass (R BSA / RBSR) with 2.45 and Dickson's quality index (DQI) with 0.85 , while $\mathrm{T} 4$ had a higher value in the lignification index (IL) with 33.68 .

\section{REFERENCES}

[1] Alvarez, C. (2016). Cocoa cultivation in the Ucayali region amounts to more than 20,000 hectares. ANDINA Peruvian news agency. Accessed June 11. 2016.Available at: https://andina.pe/agencia/noticiacultivo-cacao-region-ucayali-asciende-a-mas-20000hectareas-609323.aspx

[2] Abanto, C. (2016). Organic substrates in the production of Calycophyllum spruceanum plants (Benth. Consulted Jun 08, 2017. Available at: http://revistas.unitru.edu.pe/index.php/scientiaagrop/art icle/view/1219/1160

[3] EMPROTEC (EM Production and Technology S, A). 2017 Costa Rica. Accessed June 8, 2017.Available at: http://www.infoagro.go.cr/

[4] Lopez, S and Gil, A. (2017). Germinative characteristics of Theobroma cacao L. (Malvaceae) seeds. Peru. Vol. 24: 2, pp. 609 - 618. Accessed June 13, 2017. Available at:

http://www.scielo.org.pe/pdf/arnal/v24n2/a12v24n2.pd f

[5] Merino, E. (2013). Effect of the application of fertilizers processed with efficient microorganisms in the production of cocoa seedlings (Theobroma cacao 1.) Clone ccn- 51. Peru. Thesis Lic. Ing. Agr. NAIL. 101 p. 
ISSNe: 2617-9156

Accessed Jun 07, 2017.Available at: file: /// E: /tesis/Nueva\%20carpeta/AGR-604.pdf.

[6] National University of Ucayali (2017). Main Agricultural Meteorological Station. Pucalpa. Perú.

[7] Orozco, et ál. (2010). Plant quality diagnosis in the forest nurseries of the state of Colima. Mexico. Accessed Jun 08, 2017.Available from: http://biblioteca.inifap.gob.mx:8080/jspui/bitstream/ha ndle/123456789/1266/DIAGNOSTICO\%20DE\%20C

ALIDAD\%20DE\%20PLANTA\%20EN\%20LOS\%20V IVEROS\% 20FORESTALES\% 20DEL \% 20ESTADO $\%$ 20DE $\%$ 20COLIMA.pdf? Sequence $=1$

[8] Rodriguez, Y. (2013). Effect of the application of six doses of seaweed on germination and phenotypic characteristics in cacao (Theobroma cacao 1.) In a nursery. Ecuador. Thesis Lic. Ing. Agr. UG. 64p. Accessed Jun 08. Available at: http://repositorio.ug.edu.ec/handle/redug/2706

[9] Sáenz, et ál. (2015). Influence of four types of substrates on the growth and quality of Schizolobium amazonicum (Pashaco) seedlings in tubetes, Pucallpa-Ucayali. Peru. Thesis Lic. Ing. AFA. UNIA. 91 p.

[10] Sáenz, et ál. (2014). Plant quality of three pine species in the "Morelia" nursery, Michoacán state. Mexico. Vol. 5, no. 26. pp. 98-111. Accessed Jun 13, 2017.Available from:

http://www.redalyc.org/pdf/634/63439016008.pdf

[11] Sáenz, et ál. (2010). Plant quality in temperate forest nurseries in Michoacán. Mexico. Accessed Jun 13, 2017.Available from: http://cienciasforestales.inifap.gob.mx/editorial/index.p hp/Forestales/article/download/3960/3308

[12] Toalombo, R. (2012). Evaluation of efficient autochthonous microorganisms applied in the cultivation of white onion (Allium fistulosum). Ecuador. Thesis Lic. Ing. Agr. UTA. 95 p. Accessed Jun 08, 2017. Available from: http://redi.uta.edu.ec/bitstream/123456789/2217/1/Tesi s-22agr.pdf 